\title{
Synthesis of silica nanoparticles from rice husk ash
}

\author{
Dang Thi Thuy Nhung, Tran Hoa, Nguyen Thuy Ai Trinh, \\ Dang Van Phu, Phan Dinh Tuan, Nguyen Quoc Hien
}

\begin{abstract}
Silica nanoparticles $\left(\mathrm{SiO}_{2} \mathrm{NPs}\right)$ were synthesized from rice husk ash (RHA) by chemical treatment and calcination. The size of $\mathrm{SiO}_{2}$ NPs evaluated by transmission electron microscope (TEM) was of $20-50 \mathrm{~nm}$ and the size distribution of $\mathrm{SiO}_{2}$ NPs measured by dynamic laser scattering (DLS) was of Gaussian mode. The X-ray diffraction (XRD) pattern with only one peak at $2 \theta \sim \mathbf{2 2}^{0}$ confirmed the amorphous phase of $\mathrm{SiO}_{2} \mathrm{NPs}$. The Fourier transform infrared (FTIR) and energydispersive X-ray (EDX) spectra were also used to evaluate the functional groups and the purity of $\mathrm{SiO}_{2}$ NPs. The $\mathrm{SiO}_{2}$ NPs powder with high purity could be suitably produced by calcination of acid treated RHA at $700^{\circ} \mathrm{C}$ for $2 \mathrm{~h}$. The obtained $\mathrm{SiO}_{2} \mathrm{NPs}$ product can be potentially used for numerous purposes of application, especially as filler in paints.
\end{abstract}

Index Terms - silica nano, rice husk ash, calcination, particle size.

\section{INTRODUCTION}

Rice husk (RH) is a byproduct of rice milling process and $\mathrm{RH}$ is one of the abundant waste sources in rice growing countries such as Vietnam, Thailand, China,... It is estimated that one ton of

Manuscript Received on June 12th, 2017, Manuscript Revised November 18th, 2017.

Dang Thi Thuy Nhung, Nguyen Thuy Ai Trinh, Phan Dinh Tuan - Ho Chi Minh City of Natural Resources and Environment, 263B Le Van Sy Street, Ho Chi Minh City, Vietnam

Tran Hoa - University of Science, Vietnam National University in Ho Chi Minh City, 227 Nguyen Van Cu Street, Ho Chi Minh City, Vietnam.

Dang Van Phu, Nguyen Quoc Hien - Research and Development Center for Radiation Technology, Vietnam Atomic Energy Institute, 202A Street 11, Linh Xuan Ward, Thu Duc District, Ho Chi Minh City, Vietnam

* Corresponding author. Email: dthnhung@hcmunre.edu.vn rice is created $\sim 0.23$ ton of $\mathrm{RH}$. According to Chandrasehar et al. in India, in 1997-1998, about 26 million tons of $\mathrm{RH}$ were created [1]. In Vietnam, rice productivity is estimated of about 40 million tons/year, then the volume of RH waste is about 9.2 million tons/year. With silica content of about $10 \%$ in $\mathrm{RH}$ [2], the silica amount from $\mathrm{RH}$ in Vietnam is approximately one million ton/year. The presence of silica in the rice husk has been known since 1938 [1]. Commonly, RH is used as fuel with combustion energy of $\sim 16,720 \mathrm{~kJ} / \mathrm{kg}$ $[3,4]$. When $\mathrm{RH}$ is burned, it will create $\mathrm{RH}$ ash (RHA) with composition including: $72.1 \% \mathrm{SiO}_{2}$; $0.3 \% \mathrm{Al}_{2} \mathrm{O}_{3} ; 0.43 \% \mathrm{CaO} ; 0.5 \% \mathrm{Na}_{2} \mathrm{O} ; 0.72 \% \mathrm{~K}_{2} \mathrm{O}$; $0.15 \% \mathrm{MnO} ; 0.05 \% \mathrm{TiO}_{2} ; 0.7 \% \mathrm{MgO} ; 0.06 \% \mathrm{P}_{2} \mathrm{O}_{5}$ and $\sim 24.3 \%$ weight loss on ignition [3]. These components are subjected to change due to the different influenced factors such as geographic location, fertilizers, agro-chemicals,...[4]. Many studies on fabrication of silica from $\mathrm{RH}$ were conducted, especially silica nanoparticles $\left(\mathrm{SiO}_{2}\right.$ NPs) produced from RH in order to increase the value of agricultural waste source [2,5-9]. RHA is also an abundant source that can be used to produce $\mathrm{SiO}_{2}$ NPs $[3,4,10,11]$. Silica was used for many applications such as adsorption material, carriers, fillers,.... Recently, silica from RH was used for production of porous ceramic doped with nano silver to induce antimicrobial property for treatment of microorganisms in water [12]. In addition, silica and $\mathrm{SiO}_{2}$ NPs were also used as growth promoter and elicitor for plants [9,13-17]. In the previous work [9], we studied to prepare $\mathrm{SiO}_{2} \mathrm{NPs}$ from RH. In this work, $\mathrm{SiO}_{2} \mathrm{NPs}$ was synthesized from RHA, which is also an abundant source obtained from factories using $\mathrm{RH}$ as burning fuel, especially in Mekong Delta region. 


\section{EXPERIMENTAL.}

\subsection{Materials and chemicals}

Raw RH was supplied by rice mill factory in the south of Vietnam. Analytical reagent-grade hydrochloric acid $(\mathrm{HCl})$ was purchased from Merck, Germany. Distilled water and other chemicals were of pure grade.

\subsection{Synthesis of $\mathrm{SiO}_{2} \mathrm{NPs}$ from $\mathrm{RHA}$}

$\mathrm{SiO}_{2}$ NPs from RHA was synthesized following the procedure of Sankar et al. [11] with some modifications. Briefly, raw RH was washed with tap water to remove sand, dust, soluble substances, and other contaminants. It was then dried at $60^{\circ} \mathrm{C}$ in forced air oven (Yamato, DNF 410, Japan). The cleaned RH was burned in open environment to collect RHA. $50 \mathrm{~g}$ of RHA was stirred with $500 \mathrm{ml}$ of $\mathrm{HCl} 1 \mathrm{~N}$ at room temperature for 2 hours and allowed to stand overnight to separate the metal ions in RHA. The acid treated RHA was filtered and washed with distilled water and dried at $60^{\circ} \mathrm{C}$ in forced air oven. Finally, the treated RHA was transferred into porcelain cup and calcined at $700^{\circ} \mathrm{C}$ for 2 hours in furnace Nabertherm, Germany with a ramp rate of $\sim 20^{\circ} \mathrm{C} / \mathrm{min}$. The obtained product was $\mathrm{SiO}_{2}$ NPs white powder (Figure 1).

\subsection{Characterization of $\mathrm{SiO}_{2} \mathrm{NPS}$}

The particle size of $\mathrm{SiO}_{2}$ NPs was evaluated by transmission electron microscope (TEM), model JEM1010, JEOL, Japan and the particle size distribution of $\mathrm{SiO}_{2}$ NPs was measured by dynamic laser scattering (DLS) on a particle size analyzer, LB550, HORIBA, Japan. The X-ray diffraction (XRD) pattern was determined on D8 Advance, Brucker, Germany. Element composition of $\mathrm{SiO}_{2} \mathrm{NPs}$ was analyzed by energy dispersive $\mathrm{x}$ ray spectrometer (EDX), Horiba 7593-H. The Fourier transform infrared (FTIR) spectrum was measured on FT-IR 8400S spectrometer (Shimadzu, Japan) using KBr pellet.

\section{RESULTS AND DISCUSSION.}

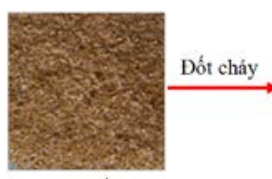

Vò trấu

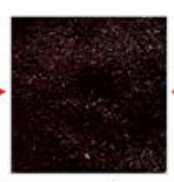

Tro trấu

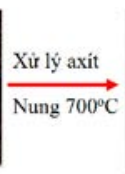

$\underset{\mathrm{ng}}{\mathrm{7}} \overrightarrow{\mathrm{C}}$

Figure 1. Brief schematic description of synthesized process of $\mathrm{SiO} 2$ NPs from RHA

The brief schematic description of synthesized process of $\mathrm{SiO}_{2}$ NPs from RHA was presented in Figure 1.

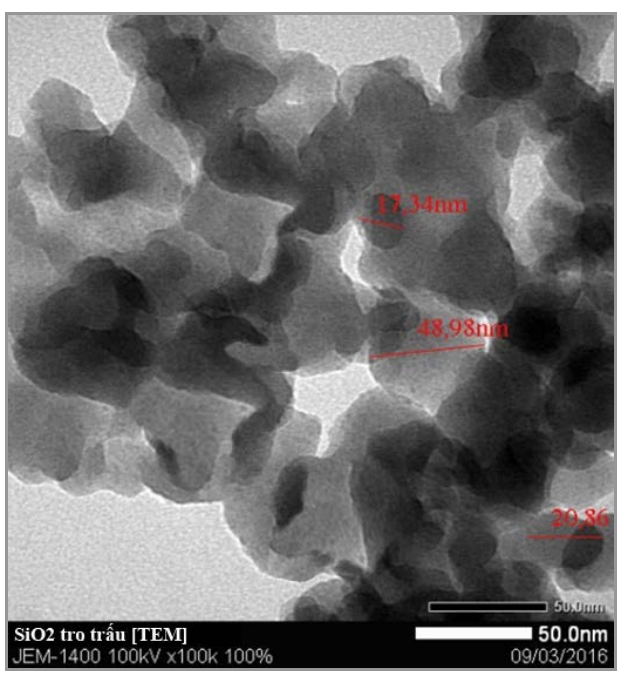

Figure 2. TEM image of $\mathrm{SiO}_{2}$ NPs from RHA

TEM image in Figure 2 showed that the particle size of $\mathrm{SiO}_{2}$ NPs from RHA was in the range from 20 to $50 \mathrm{~nm}$. This result was consistent with the result of Sankar et al. [11], but the particle size was somewhat larger than that prepared from the RH (10-30 nm) in our previous study [9].

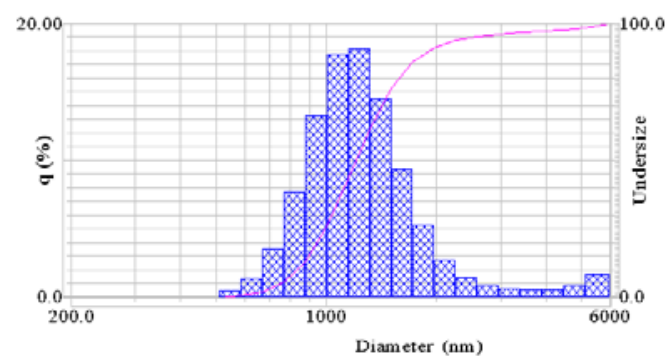

Figure 3. Particle size distribution of $\mathrm{SiO}_{2}$ NPs from RHA measured by DLS 
Result Figure 3 showed the particle size measured by DLS in the range from 800 to 1400 $\mathrm{nm}$ that was higher than the size determined from TEM (20-50 nm). The reason is that DLS method usually determines the dynamic diameter particle sizes of $\mathrm{SiO}_{2}$ NPs dispersed in water [3]. Result in Figure 3 also showed that the particle size distribution of $\mathrm{SiO}_{2}$ NPs is a bell-shaped distribution (Gaussian distribution).

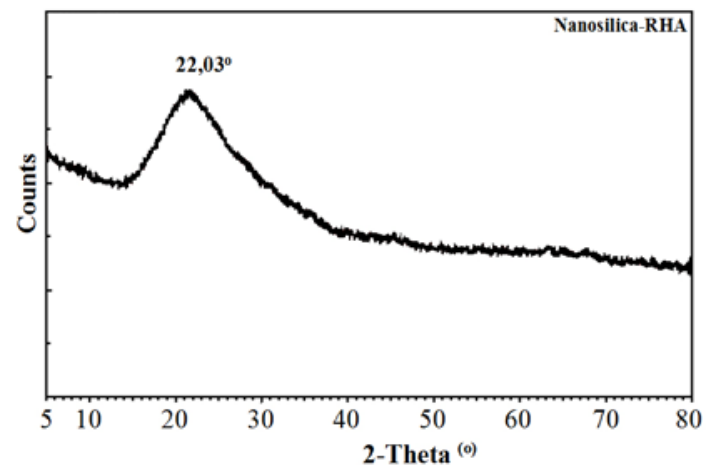

Figure 4. XRD pattern of $\mathrm{SiO}_{2} \mathrm{NPs}$ from $\mathrm{RHA}$

XRD pattern of $\mathrm{SiO}_{2}$ NPs in Figure 4 showed only 1 peak at $2 \theta \sim 22^{\circ}$. The obtained result confirmed the amorphous phase of $\mathrm{SiO}_{2} \mathrm{NPs}$ synthesized from RHA treated with acid and calcined at $700^{\circ} \mathrm{C}$ for $2 \mathrm{~h}[4,9]$.

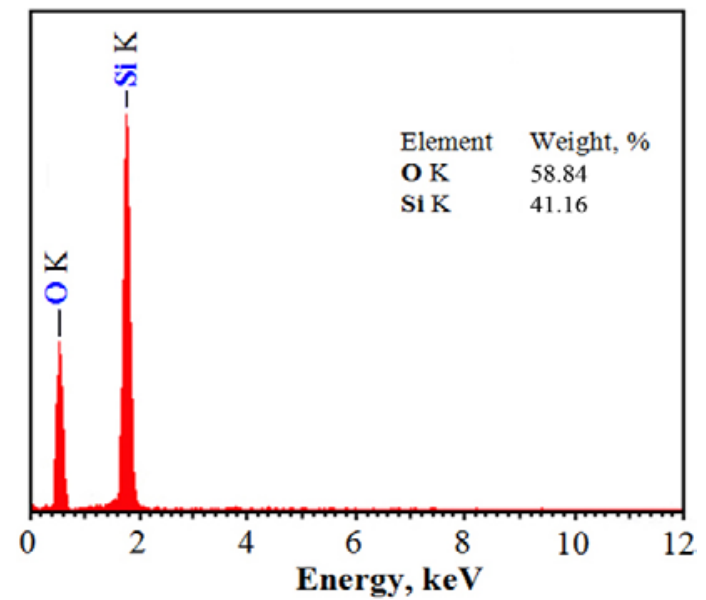

Figure 5. EDX spectrum of $\mathrm{SiO}_{2}$ NPs from RHA

The EDX spectrum of $\mathrm{SiO}_{2} \mathrm{NPs}$ in Figure 5 showed 2 peaks at $k_{\alpha}$ at 1.74 and $0.53 \mathrm{keV}$ corresponding to silicon $(\mathrm{Si})$ and oxygen $(\mathrm{O})$ with content in weight of $41.16 \%$ for silicon and $58.84 \%$ for oxygen. This result also indicated that the synthesized $\mathrm{SiO}_{2} \mathrm{NPs}$ was of high purity [4].

According to Le et al. [10], the composition of
Vietnam's RHA included $\mathrm{K}_{2} \mathrm{O}(0.39 \%), \mathrm{Al}_{2} \mathrm{O}_{3}$ (0.48\%), $\mathrm{Fe}_{2} \mathrm{O}_{3}(0.15 \%), \mathrm{CaO}(0.73 \%), \mathrm{MgO}$ $(0.55 \%), \mathrm{Na}_{2} \mathrm{O}(0.12 \%)$ and $\mathrm{SiO}_{2}(96.15 \%)$. Thus, the metal impurities in RHA was efficiently extracted by $\mathrm{HCl} 1 \mathrm{~N}$. Carmora et al. [18] reported that organic acids such as acetic acid, citric acid can be used to extract the metal ions in $\mathrm{RH}$ to increase the purity of $\mathrm{SiO}_{2} \mathrm{NPs}$ and to meet the demand for cleaner production. It can be deduced that organic acids could also be used to treat RHA.

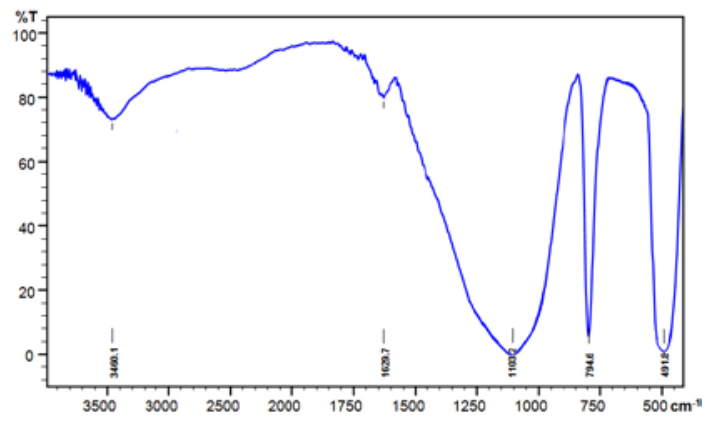

Figure 6. FTIR spectrum of $\mathrm{SiO}_{2} \mathrm{NPs}$ from RHA

The FTIR spectrum in Figure 6 exhibited characteristic peaks of silica framework, particularly at $1103 \mathrm{~cm}^{-1}$ for the O-Si-O asymmetric stretching vibration, at $794 \mathrm{~cm}^{-1}$ for the O-Si-O symmetric stretching vibration and at $491 \mathrm{~cm}^{-1}$ for the O-Si-O bending vibration $[4,11,19]$. The broad peak at $3460 \mathrm{~cm}^{-1}$ was due to the stretching vibration of surface silanol groups (Si-O-H) and physically adsorbed water $[11,19,20]$. In addition, the peak at $1629 \mathrm{~cm}^{-1}$ was assigned to $\mathrm{H}-\mathrm{O}-\mathrm{H}$ bending vibrations of trapped water molecules in the silica matrix $[19,20]$. Thus, the FTIR spectrum did not show any peaks confirming the presence of other organic and inorganic materials that demonstrated high purity of the obtained $\mathrm{SiO}_{2} \mathrm{NPs}[2,11,19,20]$.

\section{CONCLUSION.}

In this study, RHA-an abundant agriculture waste was used for the synthesis of $\mathrm{SiO}_{2} \mathrm{NPs}$. The $\mathrm{SiO}_{2}$ NPs with diameter of $20-50 \mathrm{~nm}$ and high purity was successfully obtained by calcination of $\mathrm{HCl}$ acid treated RHA at $700^{\circ} \mathrm{C}$ for $2 \mathrm{~h}$. The synthetic process is fairly suitable for large-scale production. Thus, the synthesized $\mathrm{SiO}_{2} \mathrm{NPs}$, a value-added product can be potentially used for different applications, especially as filler in paints 
and helps to diminish the concerns of RHA disposal in environment as well.

\section{REFERENCES}

[1] S. Chandrasekhar, K.G. Satyanarayana, P.N. Pramada, P. Raghavan, T.N. Gupta, "Review Processing, properties and applications of reactive silica from rice husk - an overview", J. Mater. Sci. vol. 38, no. 15, pp. 3159-3168, 2003.

[2] T.-H. Liou, "Preparation and characterization of nanostructured silica from rice husk", Mater. Sci. Eng. A, vol. 364, no. 1-2, pp. 313-323, 2004.

[3] V.P. Della, I. Kuhn, D. Hotza, "Rice husk ash as an alternative source for active silica production", Mater. Lett., vol. 57, no. 4, pp. 818-821, 2002.

[4] I.J. Fernandes, et al., "Characterization of rice husk ash produced using different biomass combustion techniques for energy", Fuel, vol. 165, pp. 351-359, 2016.

[5] N. Yalcin N., V. Sevinc V., "Studies on silica obtained from rice husk", Ceram. Int. vol. 27, no. 2, pp. 219-224, 2001.

[6] C. Real, M.D. Alcala, J.M. Criado, "Preparation of silica from rice husks", J. Am. Ceram. Soc., vol. 79, no. 8, pp. 2012-2016, 1996.

[7] W. Wang, J.C. Martin, N. Zhang, et al., "Harvesting silica nanoparticles from rice husks", J. Nanopart. Res., vol. 13, no. 12, pp. 6981-6990, 2011.

[8] J. Athinarayanan, et al., "Synthesis of biogenic silica nanoparticles from rice husks for biomedical applications", Ceram. Int., vol. 41, no. 1, pp. 275-281, 2015.

[9] D.D. Pham, et al., "Effect of nanosilica from rice husk on the growth enhancement of chili plant (Capsicum frutescens L.)," J. Sci. Technol., vol. 54, no. 5, pp. 607 $613,2016$.

[10] Le V. H., Ha T. C. N., Ha T. H., "Synthesis of silica nanoparticles from Vietnamese rice husk by sol-gel method", Nanoscale Res. Lett. 8:58, 2013.

[11] S. Sankar, et al., "Biogenerated silica nanoparticles synthesized from sticky, red, and brown rice husk ashes by a chemical method", Ceram. Int., vol. 42 , no. 4 , pp. 4875-4885, 2016.

[12] T. A. T. Nguyen, et al., "Bactericidal activity and silver release of porous ceramic candle filter prepared by sintering silica with silver nanoparticles/zeolite for water disinfection", Adv. Nat. Sci.: Nanosci. Nanotechnol, vol. 5, no. 3, (6pp), 2014

[13] M.H. Siddiqui, M.H. Al-Whaibi, "Role of nano- $\mathrm{SiO}_{2}$ in germination of tomato (Lycopersicum esculentum seeds Mill.)", Saudi J. Biol. Sci., vol. 21, no. 1, pp. 13-17, 2014.

[14] R. Suriyaprabha, et al., "Growth and physiological responses of maize (Zea mays L.) to porous silica nanoparticles in soil", J. Nanopart. Res., 14:1294, 2012.

[15] L. R. Khot, S. Maja J. M. Sankaran, R. Ehsani, E. W. Schuster, "Applications of nanomaterials in agricultural production and crop protection: A review", Crop Prot., vol. 35, pp. 64-70, 2012.

[16] L. M. Kiirika, F. Stahl, K. Wydra, "Phenotypic and molecular characterization of resistance induction by single and combined application of chitosan and silicon in tomato against Ralstonia solanacearum," Physiol. Mol. Plant Pathol., vol. 81, pp. 1-12, 2013.

[17] S. Huang, L. Wang, L. Hou Y. Liu, L. Li, "Nanotechnology in agriculture, livestock, and aquaculture in China. A review", Agron. Sustain. Dev., vol. 35, no. 2, pp. 369-400, 2015.

[18] V.B. Carmona, et al., "Nanosilica from rice husk: Extraction and characterization", Ind. Crops Prod., vol. 43, pp. 291-296, 2013.

[19] E. Rafiee, S. Shahebrahimi, M. Feyzi, M. Shaterzadeh, "Optimization of synthesis and characterization of nanosilica produced from rice husk (a common waste material)", Int. Nano Lett., 2: 29, 2012.

[20] Y. Li, et al., "Synthesis of gold nanoparticles on rice husk silica for catalysis applications", Ind. Eng. Chem. Res., vol. 54, no. 21, pp. 5656-5663, 2015.

Phan Dinh Tuan was born in Hatinh, Vietnam in 1959. He received the $\mathrm{BE}$ and $\mathrm{PhD}$ degrees in chemical engineering from the Hanoi University of Science and Technology, Vietnam.

From 1981 to 2001, he was a Researcher at Vietnam Atomic Energy Institute. Since 2001, he has joined the Hochiminh City University of Technology and then the Hochiminh City University of Natural Resources and Environment.

Professor Phan Dinh Tuan is the author of five books, more than 100 articles. His research interests include chemical and environmental engineering, material science, climate change and renewable energy. He is an Editor of the Journal Science and Technology under Vietnam Academy of Science and Technology.

Dang Thi Thuy Nhung was born in 1987, took BS in 2009 and MS in 2016 in the field of environmental science and management. She is now $\mathrm{PhD}$ student in environmental engineering.

Tran Hoa, University of Science, Vietnam National University in Ho Chi Minh City, 227 Nguyen $\mathrm{Van} \mathrm{Cu}$ Street, Ho Chi Minh City, Vietnam.

Nguyen Thuy Ai Trinh was born in 1977, took BS in 2002, MS in 2010 and joined in PhD course from 2012 at the Hochiminh City University of Technology. 
Dang Van Phu was born in 1977, took BS in 1999, MS in 2013 in chemico-biology at the Hochiminh City University of Science. He is now researcher at the Research and Development Center for Radiation Technology (VINAGAMMA).

Nguyen Quoc Hien was born in 1956 in Hatinh, Vietnam. He took BS in chemistry in 1977 and $\mathrm{PhD}$ in theoretical.and physico-chemistry in 1996 at the Hochiminh City University of Natural Science.

Professor Nguyen Quoc Hien is the author of 7 books and more than 100 papers. His research interests include nouvel method for synthesis of materials, especially nano and bioactive materials, chemical and environmental sciences.

\title{
Nghiên cứu tổng hợp nanosilica từ tro trấu
}

\author{
Đặng Thị Thùy Nhung*, Trần Hòa, Nguyễn Thụy Ái Trinh, \\ Đặng Văn Phú, Phan Đình Tuấn, Nguyễn Quốc Hiến
}

Tóm tắt- Nanosilica được chế tạo từ tro trấu bằng phương pháp xử axít và nung. Kết quả cho thấy kích thước hạt của nanosilica xác định bằng chụp ảnh kính hiển vi điện tử truyền qua (TEM) trong khoảng 20 $50 \mathrm{~nm}$. Phân bố kích thước hạt nanosilica theo kiểu hình chuông (Gaussian) được đo bằng phương pháp tán xạ lase (DLS). Phổ hồng ngoại (FTIR) và phổ tán sắc năng lượng tia $\mathrm{X}$ (EDX) cũng được sử dụng để đánh giá nhóm chức năng và độ tinh khiết của vật liệu nanosilica. Kết quả cũng cho thấy vật liệu nanosilica có thể được chế tạo một cách thuận lợi bằng phương pháp nung tro trấu đã được xử lý với axít ở nhiệt độ $700^{\circ} \mathrm{C}$ trong thời gian 2 giờ. Sản phẩm nanosilica có tiềm năng đáp ứng nhu cầu ứng dụng trong nhiều lĩnh vực, đặc biệt là làm chất độn pha sơn.

Tù $\boldsymbol{k h o ́ a - S i l i c a ~ n a n o , ~ t r o ~ t r a ̂ ́ u , ~ t h i e ̂ u ~ k e ̂ ́ t , ~ k i ́ c h ~ t h u ̛ o ̛ ́ c ~ h a ̣ t . ~}$ 